\title{
International Journal of Advanced Research in Biological Sciences
}

ISSN: 2348-8069

WWw.ijarbs.com

DOI: 10.22192/ijarbs

Coden: IJARQG(USA)

Volume 4, Issue 8 - 2017

Research Article

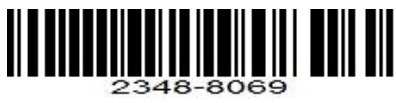

DOI: http://dx.doi.org/10.22192/ijarbs.2017.04.08.004

\section{Prevalence of Adverse Drug Reactions to Highly Active Antiretroviral Therapy (HAART) Among HIV-Positive Patients in Harar Hiwot Fana Hospital, Ethiopia}

\author{
Bantayehu Addis* and Dumessa Edessa \\ * Debre Markos Referral Hospital, Department of Pharmacy, Debre Markos, Ethiopia, \\ P. O. Box 37.
}

Corresponding Author: Bantayehu Addis, Debre Markos Referral Hospital, Department of Pharmacy, Debre Markos, Ethiopia, P. O. Box 37, E. mail: bantayehuaddis.90@gmail.com

\begin{abstract}
The introduction of highly active antiretroviral therapy (HAART) has led to significant reduction in acquired immunodeficiency syndrome (AIDS) related morbidity and mortality. Adverse drug reactions to ART are, however, the major challenges in its success. This study was mainly focused on the assessment of prevalence of ADRs of HAART in HIV patients. The data had been collected from April to May 2011 on HIV patients taking HAART in Hiwot Fana Hospital, Ethiopia. It was collected by using Open and closed ended questions. Patients were selected by simple random sampling. The study will help to identify the prevalence, nature, as well as severity of ADRs of HAART and also the awareness of patients about ADRs of highly active antiretroviral therapy. Out of 196 study subjects, 23 patients were not included; only 173 were available for evaluation. ADRs were observed in $116(67 \%)$ cases. The maximal frequency of ADRs was seen with D4T +3TC+NVP (47/173) followed by AZT+3TC+NVP (41/173) and AZT+3TC+EFV (24/173) from higher to lower. The most common observed ADRs were neurological $(47.5 \%)$ followed by gastrointestinal ADRs (25\%) and cutaneous (16.8\%). The most common neurologic ADRs were headache $(30 \%)$, muscle weakness $(28.9 \%)$ and dizziness $(16.8 \%)$. To optimize adherence and efficacy of HAART, clinicians must focus on preventing adverse drug reactions whenever possible and distinguish those that are self-limited from those that are potentially serious.
\end{abstract}

Keywords: AIDS, ADR, HAART, prevalence Hiwot Fana Hospital Ethiopia

\section{Introduction}

Acquired immunodeficiency syndrome (AIDS) is one of the most destructive epidemics in the History of mankind. An estimated 33 million people are having HIV infection worldwide as study conducted in December 2005 showed (Irshah, 2005). In Ethiopia, the adult Prevalence of HIV was estimated to be $22 \%$ in 2008. The total number of people living with HIV/AIDs in the same period was estimated to be 1 , 037, 267 adults and 68, 138 of them were children.
Furthermore, the number of deaths due to AIDS for the same period was estimated to be 58, 290 for adults and 9, 284 children (Fessehaye and Muluneh, 2009).

More than one million individuals in the US are HIV Positive with greater than 40, 000 new patients being diagnosed per year. As a study showed that the introduction of highly active antiretroviral therapy (HAART) in 1996, dramatically reduced morbidity 
Int. J. Adv. Res. Biol. Sci. (2017). 4(8): 28-35

and mortality of HIV infected patients and positively modified the discourse of the disease. Combination ART prolongs life and prevents progression of disease caused by HIV. This Combination therapy (HAART) regimen typically includes at least combination of 3 drugs, such as different association of PIs, NNRTIs and NRTIs. Although HAART is known to profoundly suppress viral replication, it increases CD4 Count and delays disease progression and death; patients on HAART commonly suffer from side effects of the drugs (Adarsh et al, 2008).

Each ART drug is associated with specific adverse effects more deaths occurring from liver failure, kidney disease, and cardiovascular complications are being observed in the patient population taking HAART. Adverse drug reaction is a response to a drug that is noxious and unintended, and that occurs at doses normally used in human prophylaxis, or therapy of disease or for the modification of physiological conditions. Many factors appear to increase the likelihood of ADRs, including age, multiple medications, and durations of drug exposure, gender, concurrent illness, and genetics (Irshah, 2005; Robert, 2005).

Studies have also shown increased rates of HAART associated lipodystrophy in women compared with men (Eric et al, 2005). Once ARV medications are started they need to be taken consistently, according to instructions, every day. Patient motivation is important to ensure that medication schedules are followed precisely (kaguu et al, 2010). Various studies have been carried out in the country in this regard to know the adverse drug reactions of highly active antiretroviral therapy among HIV patients. However, yet this study has n' been conducted at Harar Hiwot Fana Hospital, Ethiopia. Therefore, the objectives of this study were to assess the major adverse drug reactions of highly active antiretroviral therapy among HIV patients in Harar Hiwot Fana hospital, Ethiopia

\section{Patients and Methods}

\section{Study Area and Study Population}

The study was conducted at Hiwot Fana Hospital ART Providing clinic, Ethiopia. All PLWHA on HAART and greater than five years age who visited the selected hospital and who had at least two or more follow up of treatment in the clinic.

\section{Study Design and Data Collection}

A cross sectional retrospective study design by using a structured questionnaire and interviewing on patients taking HAART was conducted. In calculating the sample size, we wished to maximize discrepancy between sample and population proportion to be 0.05 and to have a $95 \%$ confidence so that discrepancy is between the limit. Since we did not have current information about the study population proportion, the variable $(\mathrm{P})=0.5$ had been used to calculate sample size. Sampling was from a list of all patients on HAART at Hiwot Fana Hospital from April to May 2011. The study subjects were selected by using simple random sampling patients on HAART that visited ART clinic during our study.

\section{Data Collection Technique and Instrument}

The data was collected by using closed and openended structured questionnaire prepared to address all the important variables. Using the questionnaire, those sampled patients on HAART in the hospital ART clinic were asked to fill the questionnaire by the group member assigned to record the data.

\section{Statistical Analysis}

After completion of data collection, the quality of data was controlled through editing, coding, classifying and tabulation. The data was analyzed by manual, scientific calculator and computer. The data was processed by classification and simplification of results, statements by sample descriptive analysis such as, tables, percentages/ charts, graphs \& figures/ for completion.

\section{Results}

Out of a total of 196 study subjects, 173 (88.3\%) were interviewed or responded to the questionnaire. The remaining $18(9.2 \%)$ were not included since the data was not able to be collected during the data collection period and $5(2.6 \%)$ responses were not relevant to the study (Figure 1). 
Int. J. Adv. Res. Biol. Sci. (2017). 4(8): 28-35

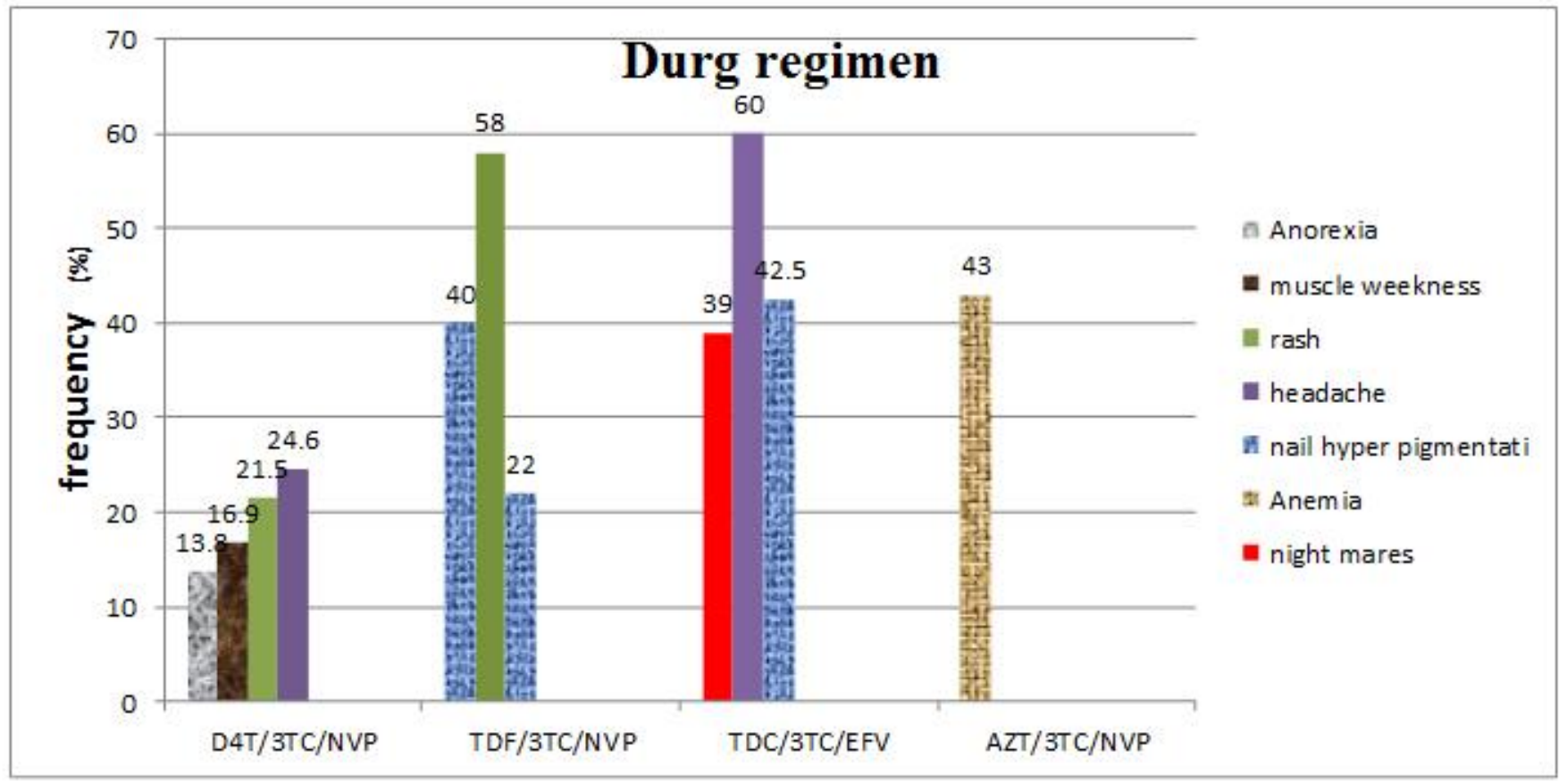

Figure 1: Frequency of ADRs by the most commonly prescribed drug regimens

Table 1: Risk details of ADRs in patients that took TDF+3TC+EFV

\begin{tabular}{|c|c|c|c|c|c|c|}
\hline \multirow{2}{*}{ ADRs } & \multirow{2}{*}{ Gender } & \multirow{2}{*}{$\begin{array}{c}\text { Number of patients that took } \\
\text { TDF+3TC+EFV (\%) 24(14.9\%) }\end{array}$} & \multicolumn{2}{|c|}{ frequency of ADRs } & \multirow{2}{*}{$\begin{array}{c}\text { ADRs } \\
\text { developed }(\%)\end{array}$} & \multirow{2}{*}{ OR } \\
\hline & & & Yes & No & & \\
\hline Headache & $\begin{array}{l}\text { Male } \\
\text { Female }\end{array}$ & $\begin{array}{c}9(37.5) \\
15(62.5)\end{array}$ & $\begin{array}{c}4 \\
11 \\
\end{array}$ & $\begin{array}{l}5 \\
4 \\
\end{array}$ & $\begin{array}{l}26.7 \\
73.3 \\
\end{array}$ & 3.44 \\
\hline Numbness & $\begin{array}{c}\text { Male } \\
\text { Female }\end{array}$ & $\begin{array}{c}9(37.5) \\
15(62.5)\end{array}$ & $\begin{array}{l}2 \\
-\end{array}$ & $\begin{array}{c}7 \\
15\end{array}$ & & 0 \\
\hline Dizziness & $\begin{array}{c}\text { Male } \\
\text { Female }\end{array}$ & $\begin{array}{c}9(37.5) \\
15(62.5) \\
\end{array}$ & $\begin{array}{l}2 \\
2 \\
\end{array}$ & $\begin{array}{c}7 \\
13 \\
\end{array}$ & $\begin{array}{l}50 \\
50\end{array}$ & 1.86 \\
\hline $\begin{array}{c}\text { Sleep } \\
\text { disturbance }\end{array}$ & $\begin{array}{c}\text { Male } \\
\text { Female }\end{array}$ & $\begin{array}{c}9(37.5) \\
15(62.5) \\
\end{array}$ & $\begin{array}{l}2 \\
2 \\
\end{array}$ & $\begin{array}{c}7 \\
13 \\
\end{array}$ & $\begin{array}{l}50 \\
50 \\
\end{array}$ & 1.86 \\
\hline Night mares & $\begin{array}{c}\text { Male } \\
\text { Female }\end{array}$ & $\begin{array}{c}9(37.5) \\
15(62.5)\end{array}$ & $\begin{array}{l}2 \\
4 \\
\end{array}$ & $\begin{array}{c}7 \\
11 \\
\end{array}$ & $\begin{array}{l}33.3 \\
66.7 \\
\end{array}$ & 1.27 \\
\hline $\begin{array}{c}\text { Muscle } \\
\text { weakness }\end{array}$ & $\begin{array}{l}\text { Male } \\
\text { Female }\end{array}$ & $\begin{array}{c}9(37.5) \\
15(62.5)\end{array}$ & $\begin{array}{l}2 \\
4 \\
\end{array}$ & $\begin{array}{c}7 \\
11 \\
\end{array}$ & $\begin{array}{l}33.3 \\
66.7 \\
\end{array}$ & 0.79 \\
\hline Gastritis & $\begin{array}{c}\text { Male } \\
\text { Female }\end{array}$ & $\begin{array}{c}9(37.5) \\
15(62.5)\end{array}$ & $\begin{array}{l}4 \\
2 \\
\end{array}$ & $\begin{array}{c}5 \\
13 \\
\end{array}$ & $\begin{array}{l}66.7 \\
33.3 \\
\end{array}$ & 5.2 \\
\hline Nausea/vomiting & $\begin{array}{c}\text { Male } \\
\text { Female }\end{array}$ & $\begin{array}{c}9(37.5) \\
15(62.5)\end{array}$ & - & $\begin{array}{c}9 \\
13 \\
\end{array}$ & - & 0 \\
\hline Anorexia & $\begin{array}{c}\text { Male } \\
\text { Female }\end{array}$ & $\begin{array}{c}9(37.5) \\
15(62.5) \\
\end{array}$ & $\begin{array}{l}2 \\
4 \\
\end{array}$ & $\begin{array}{c}7 \\
11 \\
\end{array}$ & $\begin{array}{l}33.3 \\
66.6 \\
\end{array}$ & 1.79 \\
\hline Abdominal pain & $\begin{array}{c}\text { Male } \\
\text { Female }\end{array}$ & $\begin{array}{c}9(37.5) \\
15(62.5) \\
\end{array}$ & $\overline{2}$ & $\begin{array}{c}9 \\
13 \\
\end{array}$ & & 0 \\
\hline Rash & $\begin{array}{c}\text { Male } \\
\text { Female }\end{array}$ & $\begin{array}{c}9(37.5) \\
15(62.5) \\
\end{array}$ & - & $\begin{array}{c}9 \\
11 \\
\end{array}$ & & 0 \\
\hline Hepatitis & $\begin{array}{l}\text { Male } \\
\text { Female }\end{array}$ & $\begin{array}{c}9(37.5) \\
15(62.5)\end{array}$ & $\begin{array}{l}2 \\
-\end{array}$ & $\begin{array}{c}7 \\
15\end{array}$ & & 0 \\
\hline
\end{tabular}


Int. J. Adv. Res. Biol. Sci. (2017). 4(8): 28-35

$\mathrm{OR}=$ odds ratio, $\mathrm{TDF}=$ Tenofovir, $3 \mathrm{TC}=$ lamivudine, $\mathrm{EFV}=$ Efavirenz ADR $=$ Adverse drug reaction. As shown in table 2 , in this study, 24 patients took TDF/3TC/EFV. As revealed in the table, females were observed at risk of developing headache than males $(\mathrm{OR}=3.44)$ whereas males were observed at risk of developing dizziness, sleep disturbance and gastritis than females $(\mathrm{OR}=1.86,1.86,5.2$, respectively). The other symptoms such as hepatitis, rash abdominal pain nausea/ vomiting and numbers had no association between females and males $(\mathrm{OR}=\mathrm{O})$ for this regimen.

Table 2: Risk details of ADRs in patients that took AZT + 3TC + EFV

\begin{tabular}{|c|c|c|c|c|c|c|}
\hline \multirow{2}{*}{ ADRs } & \multirow{2}{*}{ Gender } & \multirow{2}{*}{$\begin{array}{l}\text { Number of patients that took AZT + } \\
\text { 3TC+EFV } 17(9.8 \%)\end{array}$} & \multicolumn{2}{|c|}{$\begin{array}{l}\text { Frequency of } \\
\text { ADRs }\end{array}$} & \multirow{2}{*}{$\begin{array}{l}\text { Percentage of } \\
\text { ADR }\end{array}$} & \multirow{2}{*}{ OR } \\
\hline & & & Yes & No & & \\
\hline \multirow{2}{*}{ Headache } & Male & $5(29.4 \%)$ & 2 & 3 & $22.2 \%$ & \multirow{2}{*}{2.1} \\
\hline & Female & $12(70.6 \%)$ & 7 & 5 & 77.8 & \\
\hline \multirow{2}{*}{ Dizziness } & Male & $5(29.4 \%)$ & 4 & 1 & 36.4 & \multirow{2}{*}{2.86} \\
\hline & Female & $12(70.6 \%)$ & 7 & 5 & 63.6 & \\
\hline \multirow{2}{*}{$\begin{array}{c}\text { Sleep } \\
\text { disturbance }\end{array}$} & Male & $5(29.4 \%)$ & 2 & 3 & 33.3 & \multirow{2}{*}{0.75} \\
\hline & Female & $12(70.6 \%)$ & 4 & 8 & 66.7 & \\
\hline \multirow{2}{*}{ Night mares } & Male & $5(29.4 \%)$ & 2 & 3 & 33.3 & \multirow{2}{*}{1.33} \\
\hline & Female & $12(70.6 \%)$ & 4 & 8 & 66.7 & \\
\hline \multirow{2}{*}{ Muscle weakness } & Male & $5(29.4 \%)$ & - & 5 & & \multirow{2}{*}{0} \\
\hline & Female & $12(70.6 \%)$ & 4 & 3 & - & \\
\hline \multirow{2}{*}{ Gastritis } & Male & $5(29.4 \%)$ & 2 & 3 & 50 & \multirow{2}{*}{1.33} \\
\hline & Female & $12(70.6 \%)$ & 2 & 4 & 50 & \\
\hline \multirow{2}{*}{ Nausea/Vomiting } & Male & $5(29.4 \%)$ & 2 & 3 & 50 & \multirow{2}{*}{3.33} \\
\hline & Female & $12(70.6 \%)$ & 2 & 10 & 50 & \\
\hline \multirow{2}{*}{ Anorexia } & Male & $5(29.4 \%)$ & - & 5 & - & \multirow{2}{*}{0} \\
\hline & Female & $12(70.6 \%)$ & 4 & 8 & - & \\
\hline \multirow{2}{*}{ Rash } & Male & $5(29.4 \%)$ & 2 & 3 & - & \multirow{2}{*}{0} \\
\hline & Female & $12(70.6 \%)$ & - & 12 & - & \\
\hline \multirow{2}{*}{ Itching } & Male & $5(29.4 \%)$ & 2 & 3 & - & \multirow{2}{*}{0} \\
\hline & Female & $12(70.6 \%)$ & - & 12 & - & \\
\hline \multirow{2}{*}{ Ototoxicity } & Male & $5(29.4 \%)$ & - & 5 & - & \multirow{2}{*}{0} \\
\hline & Female & $12(70.6 \%)$ & 2 & 10 & - & \\
\hline \multirow{2}{*}{ Anemia } & Male & $5(29.4 \%)$ & - & 5 & - & \multirow{2}{*}{0} \\
\hline & Female & $12(70.6 \%)$ & 4 & 8 & - & \\
\hline
\end{tabular}

As shown in table 2, 127 patients took AZT/3TC/EFV and $9(53 \%)$ experienced ADR. As my study showed, for this regimen, females were at risk than males $(\mathrm{OR}=2.86)$ for headache. In other way, males were at risk for dizziness, gastritis, nausea / vomiting, nightmares and sleep disturbance than females $(\mathrm{OR}=2.86,1.3,3.33,1.3,2.1$, respectively). The other symptoms such as itching, ototoxicity and rash had no association between males and females $(\mathrm{OR}=0)$. 
Int. J. Adv. Res. Biol. Sci. (2017). 4(8): 28-35

Table 3: Risk details of ADRs in patients that took D4T $+3 \mathrm{TC}+\mathrm{NVP}$

\begin{tabular}{|c|c|c|c|c|c|c|}
\hline \multirow{2}{*}{ ADRs } & \multirow{2}{*}{ Gender } & \multirow{2}{*}{$\begin{array}{c}\text { Characteristics No of } \\
\text { patients taking } \\
\text { D4T+3TC+NVP } \\
65(37.6 \%)\end{array}$} & \multicolumn{2}{|c|}{$\begin{array}{c}\text { Frequency of } \\
\text { ADRs }\end{array}$} & \multirow[t]{2}{*}{ Percentage } & \multirow{2}{*}{ OR } \\
\hline & & & Yes & No & & \\
\hline \multirow{2}{*}{ Headache } & Male & $25(38.5 \%)$ & 2 & 23 & 12.5 & \multirow{2}{*}{6.19} \\
\hline & Female & $40(61.5 \%)$ & 14 & 26 & 87.5 & \\
\hline \multirow{2}{*}{ Vivid dreams } & Male & $25(38.5 \%)$ & 2 & 23 & 50 & \multirow{2}{*}{1.65} \\
\hline & Female & $40(61.5 \%)$ & 2 & 38 & 50 & \\
\hline \multirow{2}{*}{ Numbness } & Male & $25(38.5 \%)$ & - & 25 & & \multirow{2}{*}{0} \\
\hline & Female & $40(61.5 \%)$ & 3 & 37 & & \\
\hline \multirow{2}{*}{ Sleep disturbance } & Male & $25(38.5 \%)$ & 2 & 23 & 33.3 & \multirow{2}{*}{1.28} \\
\hline & Female & $40(61.5 \%)$ & 4 & 36 & 66.7 & \\
\hline \multirow{2}{*}{ Night mare } & male & $25(38.5 \%)$ & 2 & 23 & 33.3 & \multirow{2}{*}{1.28} \\
\hline & Female & $40(61.5 \%)$ & 4 & 36 & 66.7 & \\
\hline \multirow{2}{*}{ Muscle weakness } & Male & $25(38.5 \%)$ & 2 & 23 & 18.2 & \multirow{2}{*}{3.34} \\
\hline & Female & $40(61.5 \%)$ & 9 & 31 & 81.8 & \\
\hline \multirow{2}{*}{ Gastritis } & male & $25(38.5 \%)$ & 4 & 21 & 36.4 & \multirow{2}{*}{1.11} \\
\hline & Female & $40(61.5 \%)$ & 7 & 33 & 63.6 & \\
\hline \multirow{2}{*}{ Nausea \& Vomiting } & Male & $25(38.5 \%)$ & 2 & 23 & 33.3 & \multirow{2}{*}{1.28} \\
\hline & Female & $40(61.5 \%)$ & 4 & 36 & 66.7 & \\
\hline \multirow{2}{*}{ Anorexia } & Male & $25(38.5 \%)$ & 4 & 21 & 44.4 & \multirow{2}{*}{1.33} \\
\hline & Female & $40(61.5 \%)$ & 5 & 35 & 55.6 & \\
\hline \multirow{2}{*}{ Abdominal pain } & Male & $25(38.5 \%)$ & 2 & 23 & 33.3 & \multirow{2}{*}{1.28} \\
\hline & Female & $40(61.5 \%)$ & 4 & 36 & 66.7 & \\
\hline \multirow[b]{2}{*}{ Rash } & Male & $25(38.5 \%)$ & 2 & 23 & 14.3 & \multirow[b]{2}{*}{4.93} \\
\hline & Female & $40(61.5 \%)$ & 12 & 28 & 85.7 & \\
\hline \multirow{2}{*}{ Itching } & Male & $25(38.5 \%)$ & 4 & 21 & 3.1 & 066 \\
\hline & Female & $40(61.5 \%)$ & 9 & 31 & 85.7 & 0.66 \\
\hline & Male & $25(38.5 \%)$ & - & 25 & & \\
\hline Nephrotoxicty & Female & $40(61.5 \%)$ & 5 & 35 & & 0 \\
\hline & Male & $25(38.5 \%)$ & - & 25 & & \\
\hline Hepatitis & Female & $40(61.5 \%)$ & 2 & 38 & & 0 \\
\hline & Male & $25(38.5 \%)$ & 2 & 23 & 33.3 & \\
\hline Ototoxicity & Female & $40(61.5 \%)$ & 4 & 36 & 66.7 & 1.28 \\
\hline & Male & $25(38.5 \%)$ & - & 25 & & \\
\hline Dizziness & Female & $40(61.5 \%)$ & 4 & 36 & & 0 \\
\hline
\end{tabular}

As shown in table 3, there was a strong association between females and males for headache $(\mathrm{OR}=6.19)$ for the regimen D4T/3TC/NVP. Similarly there were strong association between females and males for developing rash $(\mathrm{OR}=4.93)$. 
Int. J. Adv. Res. Biol. Sci. (2017). 4(8): 28-35

Table 4: Risk details of ADRs in patients that took AZT + 3TC + NVP

\begin{tabular}{|c|c|c|c|c|c|c|}
\hline \multirow{2}{*}{ ADRs } & \multirow{2}{*}{ Gender } & \multirow{2}{*}{$\begin{array}{c}\text { Characteristics No } \\
\text { of patients taking } \\
\text { AZT+3TC+NVP } \\
31(37.9 \%)\end{array}$} & \multicolumn{2}{|c|}{$\begin{array}{c}\text { Frequency for } \\
\text { ADRs }\end{array}$} & \multirow{2}{*}{ Percentage } & \multirow{2}{*}{ OR } \\
\hline & & & Yes & No & & \\
\hline \multirow{2}{*}{ Headache } & Male & $14(45.2 \%)$ & 2 & 12 & 22.2 & \multirow{2}{*}{4.2} \\
\hline & Female & $17(54.8)$ & 7 & 10 & 77.8 & \\
\hline \multirow{2}{*}{ Numbness } & Male & $14(45.2 \%)$ & 2 & 12 & & \multirow{2}{*}{0} \\
\hline & Female & $17(54.8 \%)$ & - & 17 & & \\
\hline \multirow{2}{*}{ Dizziness } & Male & $14(45.2 \%)$ & 2 & 12 & 50 & \multirow{2}{*}{0} \\
\hline & Female & $17(54.8 \%)$ & 2 & 15 & 50 & \\
\hline \multirow{2}{*}{$\begin{array}{c}\text { Sleep } \\
\text { disturbance }\end{array}$} & Male & $14(45.2 \%)$ & 4 & 10 & & \multirow{2}{*}{1.25} \\
\hline & Female & $17(54.8 \%)$ & - & 17 & & \\
\hline \multirow{2}{*}{ Gastritis } & Male & $14(45.2 \%)$ & - & 14 & & \multirow{2}{*}{0} \\
\hline & Female & $17(54.8 \%)$ & 7 & 10 & & \\
\hline \multirow{2}{*}{$\begin{array}{c}\text { Muscle } \\
\text { weakness }\end{array}$} & Male & $14(45.2 \%)$ & 4 & 10 & 66.7 & \multirow{2}{*}{3} \\
\hline & Female & $17(54.2 \%)$ & 2 & 15 & 33.3 & \\
\hline \multirow{2}{*}{$\begin{array}{l}\text { Nausea / } \\
\text { Vomiting }\end{array}$} & Male & $14(45.2 \%)$ & 2 & 12 & - & \multirow{2}{*}{0} \\
\hline & Female & $17(54.8 \%)$ & - & 17 & & \\
\hline \multirow{2}{*}{ Anorexia } & Male & $14(45.2 \%)$ & 2 & 12 & - & \multirow{2}{*}{0} \\
\hline & Female & $17(54.8 \%)$ & - & 17 & & \\
\hline \multirow{2}{*}{ Abdominal pain } & Male & $14(45.2 \%)$ & 2 & 12 & - & \multirow{2}{*}{0} \\
\hline & Female & $17(54.8 \%)$ & - & 17 & & \\
\hline \multirow{2}{*}{ Diarrhea } & Male & $14(45.2 \%)$ & 2 & 12 & & \multirow{2}{*}{0} \\
\hline & Female & $17(54.8 \%)$ & - & 17 & & \\
\hline \multirow{2}{*}{ Rash } & Male & $14(45.2 \%)$ & 2 & 12 & 33.3 & \multirow{2}{*}{1.85} \\
\hline & Female & $17(54.8 \%)$ & 4 & 13 & 66.7 & \\
\hline \multirow{2}{*}{ Itching } & Male & $14(45.2 \%)$ & 2 & 12 & 33.3 & \multirow{2}{*}{1.85} \\
\hline & Female & $17(54.8 \%)$ & 4 & 13 & 66.7 & \\
\hline & Male & $14(45.2 \%)$ & 2 & 12 & - & \\
\hline Nephrotoxicity & Female & $17(54.8 \%)$ & - & 17 & - & 0 \\
\hline & Male & $14(45.2 \%)$ & - & 14 & - & \\
\hline Ototoxicity & Female & $17(54.8 \%)$ & 4 & 17 & - & 0 \\
\hline & Male & $14(45.2 \%)$ & 2 & 12 & 22.2 & \\
\hline Anemia & Female & $17(54.8 \%)$ & 7 & 10 & 77.8 & 4.2 \\
\hline
\end{tabular}

From the above table, it was also shown that females were observed as at risk of developing headache than males $(\mathrm{OR}=4.2)$ for a regimen containing AZT/3TC/NVP and the other symptoms had a weak to no association between females and males. The study showed, the most observed ADRs were associated with the use D4T/3TC/NVP and AZT/3TC/NVP. The use of D4T/3TC/NVP was associated with severe rash and moderate muscle weakness /fatigue and mild to moderate headache. Sever hepatotoxicity is observed with the use of TDF/3TC/EFV. The most changed drug regimens in most of the cases were $\mathrm{AZT} / 3 \mathrm{TC} / \mathrm{EFV}$ and TDF/3TC/EFV due to serious toxicity for males \& due to pregnancy and toxicity for females.

\section{Discussion}

In this study the majority of patients with ADRs were adults $(64.7 \%)$ and the prevalence of ADRs was higher in females $(71.2 \%)$ compared to males $(58.2 \%)$. Our finding was found to be similar to a study finding in India, the majority of ADRs were observed in adults $(51.3 \%)$ and the prevalence of ADRs was higher in female population (50\%) compared to males (42\%) as reported by (Adriana et al, 2006). This similarity is due to the use of similar methodology and similar definition of prevalence of ADRs. Therefore, both studies showed that the prevalence of ADRs was higher in female and adult population. 
Int. J. Adv. Res. Biol. Sci. (2017). 4(8): 28-35

In our study the most frequently observed ADRs were muscle weakness /fatigue, headache, rash, anorexia and night mares whereas a study in 2011 in India showed that the most commonly ADRs were hepatic toxicity followed by anemia and peripheral neuropathy (Nandakumar et al, 2011). This variation could be due to the selection of the first line and second line regimens, the difference in definition of ADRs and the use of different methodology in the study. In another study conducted in 2006 in India showed that the most frequently observed ADRs were fatigue (39\%), headache $(46.3 \%)$, anorexia $(24.4 \%)$ and anemia (12.2 $\%)$ which was consistent to our study (Batel et al, 2006).

Our study showed that women especially proved to be nevirapine based regimens, induced rash, with $85.7 \%$ of women and $14.3 \%$ of men treated by a regimen D4T/3TC/NVP; and $66.7 \%$ women and $33.3 \%$ men developed rash with the regimen AZT/3TC/NVP. This was approximately consistent with a study conducted in 2010 that women showed the development of nevirapine rash, with $9.5 \%$ of women and only $11 \%$ of men (kaguu et al, 2006). This similarity might be attributed to the fact that female gender may be a risk factor for nevirapine containing regimens.

Out of 173 patients included in our study, 117 had received nevirapine and 55 had received efavirenz based HAART. It was observed that hepatitis and rashes were observed [4(3.4\%)] and [23(7.7\%)], respectively with nevirapine and nightmares [15(27.3\%)] was observed with efavirenz whereas from other study conducted in 2006 in other country out of 1111 patients, 857 had received nevirapine and 254 had received efavirnez based HAART and it was observed that hepatitis and rashes were commonly observed [38(3.2\%)] and [\{57(6.6\%)], respectively with nevirapine and night mares [8(0.9\%)] with efavirenz [9]. This similarity of nevirapine induced hepatitis and rash is due to the fact that patients clearly reported their symptoms with the drug regimen they used in both studies. The main reason for changing HAART was mainly toxicity. At least one of the drugs changed in $40(23.1 \%)$ of the patients. Another study conducted in zewuditu memorial Hospital Addis Ababa, Ethiopia from January 2004 to December 2005 from the overall 554 clinical records of study subjects, up to $25 \%$ patients discontinue their initial HAART regimen because of toxicity effects and compliance which is almost similar to my finding. This is because of the use of similar first line regimen and similar genetic makeup (EPH, 2008).
AZT/3TC/NVP was shown to be as a risk factor for anemia whereas D4T/3TC/NVP was observed as a risk factor for headache and muscle weakness/fatigue. Males that took AZT/3TC/EFV were 3.3 times at risk for gastritis, nausea and vomiting. Males that took D4T/3TC/NVP were at risk of developing gastritis $(\mathrm{OR}=0.9)$ and nausea/vomiting $(\mathrm{OR}=0.78)$ than females. Initial HAART drug regimens of patients were highly associated with the development of ADRs and severity of ADRs (Irunde et al, 2009).

In this study, severity of ADRs were higher with D4T/3TC/NVP (28.2), AZT/3TC/NVP (15.8\%), AZT/3TC/EFV (15.6\%) and TDF/ 3TC/EFV (13.4\%); our study revealed that $40(23 \%)$ of patients were changed their initial regimen due to sever to serious toxicity, medication incompliance and for other reasons. This finding was confirmed to be consistent to other study conducted in 2009 in Mbaye and Dare Salaam, out of 1234 patients, 542(44\%) and out of 22229 patients, 932(12.4\%), respectively, in Mbaye and Dare salaam, changed their initial regimen due to sever ADRs and various reasons (Andrea, 2004).

\section{Conclusion}

The prevalence of ADRs was higher in females than males. The finding of this study showed that to optimize the efficacy of HAART, treating physicians must focus on early detection and prevention of ADRs. Highly active antiretroviral therapy with $\mathrm{d} 4 \mathrm{~T}+3 \mathrm{TC}+\mathrm{NVP}$ and AZT $+3 \mathrm{TC}+\mathrm{NVP}$ is mainly a predictor of ADRs. The finding of this study also showed that there were needs for intensive monitoring of ADRs in Hiwot Fana Hospital HIV-positive patients, especially who are adults, of female gender.

\section{Competing interest}

The author declares that I have no competing interests.

\section{Acknowledgments}

The researchers would like to acknowledge Haramaya University, College of medical sciences, and School of pharmacy for its all rounded support. We would also like to thank Hiwot Fana Hospital administrative and all health care professionals of the hospital for their cooperation throughout our data collection period. 
Int. J. Adv. Res. Biol. Sci. (2017). 4(8): 28-35

\section{References}

1. Adarsh, K., Arvid, V., Corry, P., David, M., Gregrov, A., Heidlberger, R. and Robert, S. 2008. Care of HIV positive patients in the emergency department in era of HAART. Journal of infectious disease, 52: 274-281.

2. Adriana, M.L., John, D.K. and Richard, F. 2006. Micronutrient supplementation increases CD4 Count in HIV infected individuals on HAART. Journal of Micronutrient Supplementation, 42: 524-556.

3. Andrea, S. 2004. Antiretroviral 1 therapy implications for HIV infected Women Clinical virology and infectious disease. p.1-3

4. Batel, B., Gubte, N., Patel, A., Pujari, S. and Shan, N. 2006. Neverapine Versus evavirenz based ARV Therapy. International Journal of Medicine, 54: 915-917

5. EPH, 2008. Sponsored Masters Theses on HIV/AIDS No5, pp.87 - 88

6. Eric, D., Gray, H. and Jean, P. 2005. HAARTrelated nephropathies in HIV infected patients. Journal of kidney international, 67: 394-400.
7. Fessehaye, A. and Muluneh, A. 2009. Hematologic abnormalities among children on HAART. Ethiopian Journal of Health science, 19: 83-89.

8. Irshah, D. 2005. Adverse effects of antiretroviral therapy in HIV-1 infected children. Journal of tropical pediatrics, 152: 241-248.

9. Irunde H., Minzi O.M. S., Moshiro C 2009. HIV patients presenting adverse drug events caused by HAART. Journal of Micronutrient Supplementation, 41: 5-9

10. Kaguu, L., Manngi, S. and Mutigi, W. 2010. Efficacy and challenge of Adherence to antiretroviral therapy. International Journal of Medicine, 2: 25-28.

11. Nandakumar, K., Rajesh, R. and Yasangar, S. 2011. HAART induced ADRs in Indian HIV/AIDS patients. Journal of Micronutrient Supplementation, 40: 48-55

12. Robert, M. 2005. Adverse drug reactions and Clinical toxicology. In: The science and practice of pharmacy, David V. T (Ed), $21^{\text {st }}$ Ed. Vol 2,New delhi,philodelphia, Pp. 1221-1228.

\begin{tabular}{|c|c|}
\hline \multicolumn{2}{|c|}{ Access this Article in Online } \\
\hline \multirow{2}{*}{ 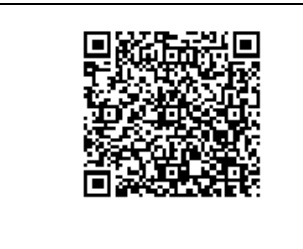 } & $\begin{array}{l}\text { Website: } \\
\text { www.ijarbs.com }\end{array}$ \\
\hline & \multirow[t]{2}{*}{$\begin{array}{l}\text { Subject: } \\
\text { Pharmacy }\end{array}$} \\
\hline $\begin{array}{c}\text { Quick Response } \\
\text { Code }\end{array}$ & \\
\hline DOI:10.22192/ijarb & 17.04 .08 .004 \\
\hline
\end{tabular}

How to cite this article:

Bantayehu Addis and Dumessa Edessa. (2017). Prevalence of Adverse Drug Reactions to Highly Active Antiretroviral Therapy (HAART) Among HIV-Positive Patients in Harar Hiwot Fana Hospital, Ethiopia . Int. J. Adv. Res. Biol. Sci. 4(8): 28-35.

DOI: http://dx.doi.org/10.22192/ijarbs.2017.04.08.004 